\title{
PEDAGOGICAL CONDITIONS FOR THE DEVELOPMENT OF ANALYTICAL THINKING IN APPLICANTS OF HIGHER TECHNICAL EDUCATION
}

\author{
Liudmyla Zelenska ${ }^{1}$, Olga Dovgal ${ }^{2}$ \\ ${ }^{1}$ Doctor of Pedagogical Sciences, Professor, Professor of the Education and Innovative Pedagogy \\ Department, H.S. Skovoroda Kharkiv National Pedagogical University, Kharkiv, Ukraine, e-mail: \\ lyudmyla.zelenska@hnpu.edu.ua, ORCID: https://orcid.org/0000-0002-3324-5173 \\ ${ }^{2}$ Postgraduate student of the Education and Innovative Pedagogy Department, H.S. Skovoroda Kharkiv \\ National Pedagogical University, Kharkiv, Ukraine, e-mail: dovgall_olga@ukr.net, ORCID: \\ https://orsid.org/0000-0002-6952-4895
}

\begin{abstract}
In the context of globalization, informatization and automation of labor, there is a need to develop flexible skills that serve as the basis for personal and professional implementation. The World Economic Forum has published the TOP-10 flexible skills that would be demanded in production in 5 years. The first positions are being taken by analytical thinking and innovation. In view of this, there is a need to develop analytical thinking skills for applicants of higher technical education already at the stage of their vocational training so that they are competitive in the labor market. So, the system of higher technical education faces a problem is how to create conditions for the training of a future specialist in engineering specialties, ready to adapt to the new realities of life, capable of personal and professional development and career growth, to teach to distinguish the essential from the inessential, to build fro, more complicated to more simple. The article analyzes the scientific literature on the interpretation of the concepts of "analytical thinking" and "pedagogical conditions". On the basis of the received information, pedagogical conditions for the development of analytical thinking of applicants for higher technical education in the learning process (ensuring motivation for the development of analytical thinking as the way of professional formation; creating cases of professionally oriented tasks and exercises; mastering analytical tools to perform relevant function duties; reflection at all stages of analytical thinking development. To substantiate the pedagogical conditions for the development of analytical thinking of applicants of higher technical education (bachelor's level) such theoretical methods as analysis, synthesis, generalization, abstraction have been used. It has been established that due to developed analytical thinking, future engineers acquire the ability to apply knowledge, skills and personal qualities in the process of analytical activity. Ability to receive qualitatively new knowledge for prompt and productive provision of the decision-making process; work with large amounts of information; they develop attentiveness, long-term memory, intuition, observation, perseverance, responsibility, creativity, attention to attention. o trifles, wide horizons, the ability to bring the matter to completion, etc.
\end{abstract}

Keywords: analytical thinking, pedagogical conditions, applicants for higher technical education, motivation, cognitive interest, educational and methodological support, reflexivity.

JEL Classification: I 24, I 29

Formulas: 0; fig.: 0; tabl.: 0; bibl.: 19

Introduction. Fast changes in the world would take steps up to rethink the necessary skills of future specialists. There is no doubt that the fourth industrial revolution should the key factor in changing of demanded skills. In October 2020, the World Economic Forum published another list of skills important for future success. The first place in this list belong to analytical thinking [19].

Literature review. The issue of research of analytical thinking is devoted to the work of such scientists as S. Rubinstein, O. Tikhonirov, A. Zhdan, A. Rean, L. Stolyarenko, M. Hrynyova and many others. The leitmotif of these works is the 
idea that analytical thinking takes on the role of the main tool of scientific knowledge. Researchers characterize it as a separate particular type of thinking, being carried out through logical operations, according to which phenomena and objects are being considered on separate particular and common grounds [16, p. 151].

The researchers emphasize that analytical thinking cannot be considered solely in the context of information analysis. It also contributes to its synthesis, providing a high level of theoretical generalizations. This phenomenon S. Rubinstein called "analysis through synthesis" [12, p.141], since the analysis always acts in connection with abstraction, generalization and other mental operations.

Scientists are unanimous in that the analytical style of thinking is focused on systematic and versatile consideration of a point or problem in those aspects that are being set by objective criteria [14, p. 185]. Its features are logic, methodicality, detailed study of the problem, reflexivity. In fact, one life experience, common sense or intuitive logic is not enough to solve any problems. An important element is logic.

O. Tikohomyrov believes that logic belongs to the system of sciences that make up the core of spiritual culture and perform important functions in society. In view of this, it is valuable for a novice specialist to acquire a logical culture of thinking. This will enable you to achieve true knowledge, avoid logical mistakes under the influence of emotions, subjective perception and conscious control of your own thoughts. Systematically assimiling the methods of scientific knowledge in the process of educational activity, the young specialist forms his own logical culture of thinking.

Revealing the features of analytical thinking, researcher O. Tikomyrov emphasizes that "analytical thinking is deployed in time and has clearly defined stages, to a significant extent represented in the awareness of the thinking person" $[15, \mathrm{p} .10]$.

At the same time, researchers (A. Muranov, L. Stolyarenko) in their works pay attention to the fact that analytical thinking derives from the logical culture of thinking. The culture of thinking involves the skills of thinking analysis, the use of methods of rational thinking and argumentation. According to A. Muranov, logical culture is a set of means of processing information and techniques for organizing thinking activities [10, p. 92].

Unfortunately, in the practice of high school quite often we may observe the fact that students cannot express their own opinions, do not have a minimum of logical skills. This indicates a low level of logical culture among them. Taking this fact into consideration, the fundamental development among applicants of analytical thinking should be the basis of their logical culture. In the process of mastering any academic discipline, students should freely operate basic concepts, in order to be able to classify and distinguish them.

The analysis of psychological and pedagogical literature shows that in the process of organizing a certain activity to achieve high efficiency, it is necessary to highlight certain conditions for the implementation of a set of these processes. It is significant to note that L. Vyshovskiy emphasized the necessity of "creation of the conditions in advance as highly necessary for the development of important mental qualities, although they are also "not ripe" for its self-functioning" [2, p. 55]. 
According to the researcher E. Karpenko, the pedagogical conditions include psychological and pedagogical, methodological, organizational, informational, which are being formed during the pedagogical process consciously and should ensure the most effective course of this process [5, p. 6].

In pedagogical literature, such definition of pedagogical conditions is also common - these are "persistent circumstances that determine the state and development of functioning pedagogical systems" [13,p. 34].

Aims. The purpose of the article is to substantiate the pedagogical conditions for the development of analytical thinking for applicants for higher technical education in the learning process.

Methods. To substantiate the pedagogical conditions for the development of analytical thinking in higher education applicants in the process of study, the following methods of cognition have been used such as synthesis, analysis, generalization, abstraction.

Results. In the process of scientific research, it was established that the ability to think analytically is defined as a qualification characteristic of specialists in various specialties and fields of knowledge. It is mostly demanded while performing tasks in logistics, economics, programming, sales, etc. - that is, in industries where it is necessary to analyze information and make decisions. The ability to analytical thinking is basic for specialists of engineering specialties.

Analytical thinking for specialists of engineering specialties is important for understanding the clarity of individual stages in the knowledge of technological processes of production, full awareness of its content, as well as the methodology of operations used. (here a paragraph should be a provided why analytical thinking is highly important for engineers)

Specialist engineering specialty, who has analytical thinking at his workplace

- with higher efficiency solves production tasks, knows how to distribute them in complexity and importance;

- faster solves the current tasks;

- is able to control emotions, preventing their influence on decision-making.

The above-mentioned components were taken into account in order to justify the pedagogical conditions for the development of analytical thinking in applicants of higher technical education (bachelor's level).

Under pedagogical conditions of formation of analytical thinking of students of engineering specialties (141 - Electric power engineering, Electrical engineering and electromechanics, 161 - Chemical technologies and engineering, 185 - Oil and gas engineering and technologies, 191 - Architecture and urban planning, $192-$ Construction and civil engineering, 194 - Hydraulic engineering, water engineering and water technologies) of higher education institutions will understand purposeful selection, construction and usage of content elements, methods (techniques), forms of training for the development of analytical thinking, such as:

1. Ensuring he motivation for the development of analytical thinking as a way of professional formation;

2. Creating cases of professionally-oriented tasks and exercises; 
3. Mastering analytical tools to perform relevant function duties;

4. Introspection at all stages of the development of analytical thinking.

Discussion. The first pedagogical condition includes motivation as an awareness of the need for professional development, which turns into a motive, striving to realize it, an interest in achieving professionally significant knowledge, skills, qualities, qualities, values, etc., that is, everything that encourages the student to act, activity in cognitive learning activities. Strengthening of the motif goes with continuous repetition, which leads to its transformation into a character trait, into a constant motivated potentiality [11]. It is worth noting that in psychology, motivation is being included into everything that encourages activity and can be realized in a number of forms: interests, aspirations, beliefs and settings.

Cognitive interest is a special kind of human interest; its essence is analyzed by many psychologists and educators (V. Bondar, V. Vergasov, P. Halperin, I. Zimnya, B. Lykhachev, O. Moroz, G. Shchukin) and defined as an interest in action, purposeful search for effective ways to develop cognitive activity. Cognitive interest is the basis of educational activity, in other words, the need of the student to master the missing knowledge [6]. This is possible on the basis of the formation of the need for constant appeal to high-quality sources of information, the ability to select and critical comprehend, to ensure the possibility of familiarization with alternative positions, ideas, interpretations of facts, etc. [7].

Thus, the first pedagogical condition ensures the formation of a stable interest of future specialists towards professional activities, the need for such activities, the direction to perform professional functions, the desire for creative solution of professional problems, the aspirations of continuous professional and career growth and its self-improvement.

The second pedagogical condition is to create cases of professionally-oriented tasks and exercises for the development of analytical thinking.

The essence of the case method - the method of situational analysis - is that those who study are being invited to realize the current professional situation, the description of which at the same time reflects not only some practical problem, but also actualizes a certain set of knowledge that must be learned in order to solve it. The main point of this problem is that there are not any unambiguous solutions [3, p.7].

Professionally-oriented tasks are a complex set of educational tasks transformed in such a way that their solution simulates the tasks faced by students in future professional activities. Each posture contains a full cycle of solving the problem from problem solving, updating the knowledge gained during training, to independently searching for the necessary literature, developing a plan for solving this problem and introspection and developing a program of self-improvement [8]

In other words, the second pedagogical condition will initiate to the activation of cognitive activity of those students due to the existing understanding of the connection of educational material with its practical component.

The third pedagogical condition is important in view of the activity and technological component, since future engineers should acquire the skills to 
practically implement the principles, approaches, apply methods and methods of analytical research. Analytical methods should be used to a greater extent, in particular comparative analysis, cause-and-effect, content analysis, semantic analysis, graphic, structural, expert evaluation, scenario method, discriminant method, etc. We believe that ensuring the third pedagogical condition makes it possible for the student to master the system of methods, which will allow him to choose such tools in professional activities that will guarantee the optimal and effective solution of a certain problem.

The fourth condition is significant and necessary at all stages of the development of analytical thinking. L. Vygotsky [1] emphasized the importance of reflexivity as a constructional characteristic of consciousness. Reflection is a source of internal experience, a way of self-knowledge and a necessary means of thinking. It helps to learn, develop skills, avoid repeating mistakes and constantly to improve. In the process of professional training, reflection allows the student to realize his own individuality, uniqueness and purpose, which are found in the analysis of his subject activities and its products.

P. Shchedrovitsky [17] notes that development occurs only when controlled reflection is involved, thanks to which the schemes of activity are distinguished ways to solve problems or reasoning. In addition, reflection is the basis of selfeducation of the individual to development; therefore, only as a result of introspection, self-correction, self-management, it is possible to form the analytical competence of future specialists in engineering specialties.

Provision of these conditions is based on methodological approaches: personally-oriented, systemic, active, competent - in order to acquire independence by the student both in study and in further professional activity; self-confidence, in their own professional training; formation of an individual style of activity; ability to analyze and consider working situations in more detail and build their holistic image; successful skills in building relationships and connections between various engineering workflows.

Informed conditions echoes the pedagogical conditions that were developed by Shevchenko S. M. [16] (orientation of the student on the independent formation of mental operations; encouraging the student to form analytical thinking; intensification of self-control in the process of formation of), and correlate with the conditions developed by the Ishchenko V. S. [4] formation of analytical competence of future specialists in records keeping and information activities (formation of sustainable motivation for analytical activity as a way of professional development and career growth due to the specifics of the chosen direction of training; creation of highquality educational and methodological support (enrichment of forms, methods, teaching methods, adequately defined content of preparation for analytical activities) of the educational process; mastering future specialists of analytical tools to perform relevant function duties; stimulation of the reflexive position of future specialists at all stages of development of analytical competence).

Conclusion. Due to the development of analytical thinking, the student acquires the ability to apply knowledge, skills and personal qualities in the process of 
analytical activity in order to obtain qualitatively new knowledge for prompt and productive provision of the decision-making process in various fields of activity and acquires such personal qualities as the ability to work with large amounts of information, attentiveness, long-term memory, developed intuition, observation, perseverance, responsibility, creativity, attention to detail, broad-minded outlook, the ability to bring the matter to completion, etc.

For students of engineering specialties, acquiring analytical thinking would help to understand complex technological processes and production modes, to learn how to foresee possible problems in the production process and the implementation of approaches to eliminating negative factors of influence on the workflow.

Perspectives for further scientific research are connected with the development of pedagogical and methodological tools for the implementation of pedagogical conditions for the development of analytical thinking in applicants of higher technical education in the process of training both professionally oriented disciplines and disciplines of the general training cycle.

Author contributions. The authors contributed equally.

Disclosure statement. The authors do not have any conflict of interest.

References:

1. Vygotskij, L. S. (1982), Dinamika $i$ struktura lichnosti podrostka. Khrestomatiya po vozrastnoj $i$ pedagogicheskoj psikhologii [Dynamics and structure of the personality of the teenager. Textbook on Age and Educational Psychology], Moscow: Pedagogika, 138-142 [in Russian].

2. Vygotskij, L.S. (1960), Razvitie vysshikh psikhicheskikh funkcij [Development of higher mental functions], Moscow: Izd-vo APN RSFSR [in Russian].

3. L. O. Savenkovoi, V. M. Prykhodko (Eds.) (2009), Zbirnyk mini-keisiv z dystsypliny «Komunikatyvni protsesy $u$ navchanni» [Collection of mini-cases in the discipline "Communicative processes in training"], Kyiv: KNEU [in Ukrainian].

4. Ishchenko, V.S. (2017), Pedahohichni umovy formuvannia analitychnoi kompetentnosti maibutnikh fakhivtsiv iz dokumentoznavstva ta informatsiinoi diialnosti [Pedagogical conditions of formation of analytical competence of future specialists in records keeping and information activity]. Narodna osvita. Elektronne naukove fakhove vydannia, 3(33). Retrieved from https://www.narodnaosvita.kiev.ua/?page_id=5017 [in Ukrainian].

5. Karpenko, Ye. M. (2014), Pedahohichni umovy formuvannia informatsiino-analitychnykh umin maibutnikh uchyteliv inozemnykh mov u protsesi fakhovoi pidhotovky [Pedagogical conditions for the formation of information and analytical skills of future teachers of foreign languages in the process of professional training] (avtoref. dys. ... kand. ped. nauk: 13.00.04), Zhytomyr [in Ukrainian].

6. Korchahina, H. S. (2014), Rozvytok piznavalnoho interesu maibutnikh uchyteliv muzychnoho mystetstva $v$ protsesi fakhovoi pidhotovky [Development of cognitive interest of future teachers of musical art in the process of professional training], Onovlennia zmistu, form ta metodiv navchannia i vykhovannia $v$ zakladakh osvity: Zbirnyk naukovykh prats. Naukovi zapysky Rivnenskoho derzhavnoho humanitarnoho universytetu, Vyp. 9 (52). S. 31-34, Rivne: RDHU [in Ukrainian].

7. Linkina, N. N. (2002), Pedagogicheskie usloviya modernizacii estestvennonauchnogo obrazovaniya pedagogicheskogo kolledzha $v$ edinom informacionnom prostranstve [Pedagogical conditions of modernization of natural science education of pedagogical college in the unified information space] (dis. ... kand. ped. nauk : 13.00.01), Rostov na Donu [in Russian].

8. Muzyka, O. L., Maistrenko, T. M., Osnadchuk, Yu. O. (2007), Vyshchii osviti - yevropeiskyi riven: dosvid vprovadzhennia kredytno-modulnoi systemy navchannia na sotsialno-psykholohichnomu fakulteti ZhDU imeni Ivana Franka [Higher education - European level: experience in the implementation of creditmodular training system at the socio-psychological faculty of Ivan Franko National University of Lviv], Zhytomyrshchyna: mynule, sohodennia, postup u maibutnie: Naukovyi zbirnyk, Za zah. red. P. Iu Saukh, O. M. Shvydak, I. I. Iarmoshyk ta in., T.2, Zhitomir: Vyd-vo ZhDU im. I.Franka, S. 65-75 [in Ukrainian]. 9. Muranov, A. (1995), $V$ klasse kak v celom mire [In the classroom as in the whole world], Narodnoe obrazovanie, № 6. S. 91-93 [in Russian]. 
10.Novikov, A. M., Metodologiya obrazovaniya. Izdanie vtoroe [Methodology of education. Second edition], Moscow: Ehgves [in Russian].

11.Petrenko, L. M. (2013), Teoriia i praktyka rozvytku informatsiino-analitychnoi kompetentnosti kerivnykiv profesiino-tekhnichnykh navchalnykh zakladiv : monohrafiia [Theory and practice of development of information and analytical competence of heads of vocational educational institutions: monograph], Dnipropetrovsk: IMA-pres [in Ukrainian].

12.Rubinshtejn, S. L. (1958), O myshlenii $i$ putyakh ego issledovaniya [On thinking and ways of his research], Moscow: Nauka [in Russian].

13.Slastenin, V. A., Isaev, I. F., Mishchenko, A. I., Shiyanov, E. N. (2002), Pedagogika : [ucheb. posob. dlya stud. ped. ucheb. zaved. [Pedagogy], Moscow : Shkol'naya Pressa [in Russian

14.Stolyarenko, L. D. (2000), Osnovy psikhologii. Izdanie tret'e [Psychology foundations], Rostov na Donu : Feniks [in Russian].

15.Tikhomirov, O. K. (1984), Psikhologiya myshleniya. Ucheb.posobie [Psychology thinking], Moscow: MGU [in Russian].

16. Shevchenko, S. M. (2007), Pedahohichni umovy formuvannia analitychnoho myslennia studentiv vyshchykh tekhnichnykh navchalnykh zakladiv [Pedagogical conditions for the formation of analytical thinking of students of higher technical educational institutions], Pedahohika, psykholohiia ta medykobiolohichni problemy fizychnoho vykhovannia $i$ sportu: naukova monohrafiia za redaktsiieiu prof. Yermakova S.S., Kharkiv: KhDADM (KhKhPI), № 3. S. 151-154.

17. Shchedrovickij, P. G. (1993), Ocherki po filosofii obrazovaniya (stat'i i lekcii) [Essays on the philosophy of education (articles and lectures)], Moscow: Pedagogicheskij centr "Ehksperiment", $154 \mathrm{~s}$ [in Russian].

18.Chornyi, O., Herasymenko, L., Zelenska, L. (2020), Diagnosing of Competenciens' Formation of the Future Electro-mechanic Nechnicians by Means of Professionally-oriented Tasks, Proceedings of the International Conference on 2020 IEEE 25th International Conference on Problems of Automated Electrodrive. Theory and practice (PAER), PAER [in English].

19.World Economic Forum, (2021) Retrieved from https://www.weforum.org/agenda/2020/10/top-10-workskills-of-tomorrow-how-long-it-takes-to-learn-

them?utm_source=facebook\&utm_medium $=$ social_scheduler\&utm_term=Education\%20and\%20Skills\&utm _content $=21 / 10 / 2020 \% 2021: 30 \&$ fbclid $=I w A R 3 h \_y M N Y 73 A-W r E H 7 F j a p$ -

WqRNCoqMTaqlngJeIhHZXdyGMmO4ppJCZgAk [in English]. 